\title{
2007 Farm Bill: Attitudes of Specialty Crop Growers to Alternative Policy Options ${ }^{1}$
}

John VanSickle and Richard Weldon ${ }^{2}$

\section{Introduction}

The Farm Security and Rural Investment Act of 2002 (hereafter referred to as the 2002 Farm Bill) was signed into law on May 13, 2002. It governs federal farm programs through 2007. Its provisions call for the following:

- Supporting production for a reliable, safe, and affordable supply of food and fiber.

- Promoting stewardship of agricultural land and water resources.

- Facilitating access to American farm products at home and abroad.

- Encouraging continued economic and infrastructure development in rural America.

- Ensuring continued research to maintain an efficient and innovative agricultural and food sector.

Specialty crop listening sessions were held in Florida as part of a 2007 Farm Bill: Specialty Crops Policy Options and Consequences project funded by the California Institute for the Study of Specialty Crops (CISSC). The objective of the listening sessions was to assess the knowledge and attitudes of specialty crop growers on the current Farm Bill and to assess their perceived needs in an expected 2007 Farm Bill.

The purpose of holding listening sessions was to learn about the views of specialty crop growers toward the current farm bill and what they would like to see addressed in the next farm bill. These listening sessions were held in conjunction with listening sessions in the other key fruitful rim states participating in the CISSC project (Arizona, California, Michigan, New York, Texas, and Washington).

Listening sessions in Florida were held in the fall and winter of 2005/06. The first session was held at the Florida Fruit and Vegetable Association (FFVA) annual meetings in late September 2005 (USDA, 2005). The U.S. Secretary of Agriculture held a U.S. Department of Agriculture listening session at these meetings, and comments made by participants were documented. Approximately 250 specialty crop industry growers and marketers participated in that

1. This is EDIS document FE674, a publication of the Food and Resource Economics Department, Florida Cooperative Extension Service, Institute of Food and Agricultural Sciences, University of Florida, Gainesville, FL. Published October 2006. Please visit the EDIS website at http://edis.ifas.ufl.edu.

2. John VanSickle, Professor and Director, International Agricultural Trade and Policy Center, Food and Resource Economics Department; and Richard Weldon, Associate Professor, Food and Resource Economics Department, Florida Cooperative Extension Service, Institute of Food and Agricultural Sciences, University of Florida, Gainesville, FL.

The Institute of Food and Agricultural Sciences (IFAS) is an Equal Opportunity Institution authorized to provide research, educational information and other services only to individuals and institutions that function with non-discrimination with respect to race, creed, color, religion, age, disability, sex, sexual orientation, marital status, national origin, political opinions or affiliations. U.S. Department of Agriculture, Cooperative Extension Service, University of Florida, IFAS, Florida A. \& M. University Cooperative Extension Program, and Boards of County Commissioners Cooperating. Larry Arrington, Dean 
session. Speakers generally voiced the opinion that specialty crops are an important crop in U.S. agriculture. While Florida is the tenth leading state in agricultural cash receipts and the fifth leading crop-producing state, it received less than one percent of the government payments given to farmers in calendar year 2003. It directly accounts for more than 338,000 jobs and $\$ 50.8$ billion in economic activity in Florida. Participants noted that agriculture is important in Florida but faces many challenges. The sheer size and diverse nature of agricultural production in Florida and in specialty crops nationwide makes policy and trade-related matters exceedingly important. Nationwide, specialty crops account for more than $28 \%$ of net farm receipts. The message emanating from this listening session was that specialty crops deserve more attention in the next farm bill than has been given in previous farm bills.

In addition to observing the listening session held by the U.S. Department of Agriculture, individual listening sessions were held with several Florida agricultural groups. A listening session was held with the Florida Nursery Growers and Landscape Association (FNGLA) in December 2005. The listening session with FNGLA was held in their corporate offices in Orlando, Florida, and was attended by 15 members of that association. The listening session was structured where the growers were given a brief overview of the 2002 Farm Bill, followed by a discussion about opportunities in the 2007 Farm Bill. It ended with a survey that was distributed to the group and filled out at the close of the meeting. The survey was structured to document the views of attendees on specific aspects of potential farm bill legislation. A second individual listening session was held with the Florida Tomato Exchange in conjunction with a Board Meeting for the group in January 2006. There were 20 members of that association in attendance. The meeting was structured similar to the meeting with the FNGLA. A presentation was made to outline the current policies in the 2002 Farm Bill and then the group was asked to discuss features they would like to see implemented in the 2007 Farm Bill. Again, the survey was distributed and the group was asked to return those sometime over the following week. A third, and final, listening session was held in the corporate offices of the Florida Farm Bureau with 15 members of their
International Trade Advisory Committee. Again, the meeting was structured with a brief overview of the 2002 Farm Bill, followed by discussion. The survey was shared with this group as well. In all, 50 attended the three Florida agricultural group listening sessions, and 25 surveys were returned and are summarized below.

\section{Summary of Comments from the Listening Sessions}

Each of the listening sessions (other than the USDA session) was structured so that a presentation was made to outline the basic goals and programs of the 2002 Farm Bill and then the participants were allowed to discuss opportunities for the 2007 Farm Bill. Much of the general discussion focused on how the specialty crop sector had prospered without the aid of an income support program, with many voicing an opinion that income support programs would be bad for specialty crop growers. The general consensus can be summed up from one of the early comments made at the meeting with the Florida Tomato Exchange. One of the prominent growers stated, "Why are we wasting our time talking about the Farm Bill? This industry has survived without the federal aid of income support and we don't need it!" Most of the participants voiced the belief that they benefit from the specialty crop planting restriction placed on program crop acreage. These growers are concerned about the potential loss of the planting restriction, and some would entertain income support payments to growers only as compensation for value that may be lost if the planting restriction is removed from the 2007 Farm Bill.

Many growers in the specialty crop sector tend to think of the 2002 Farm Bill as income support for program crops. Only after further discussion did many understand the role of the farm program in defining programs outside the Title I Commodity Programs. It would be fair to say the general impression is that these growers feel they are more competitive because they do not participate in Title I Commodity Programs. When they became more aware of the other programs covered by the 2002 Farm Bill, they developed a better understanding of the benefits provided in this legislation. 


\section{Summary of Survey Results}

Some interesting results came from the surveys that were administered to the attendees of the listening sessions held with the producer groups in Florida. The respondents were asked to rank programs/issues that could be affected by the 2007 Farm Bill with respect to the importance of the issue/program to their organization. They were also asked for more detail on issues related to each of these programs. The following discussion presents the rankings of the major issues presented in the survey and relates the detailed information from subsequent questions to this ranking.

The issue that was seen as most important to the respondents was labor. While labor does not have a title in the current Farm Bill and is not likely to be addressed in the 2007 Farm Bill, it is nonetheless viewed as a critical issue facing this industry. The respondents were asked to identify the labor issues that were of most concern to them. Two issues stand out as most important: labor availability and the guest worker program. Both of these issues are being discussed in light of new legislation for immigration reform. Congress has brought national attention to it, so it is not surprising that this issue is seen as critical to this industry. Labor is an important resource requirement for producing most specialty crops and much of the industry would struggle to remain competitive without the availability of foreign labor.

The issue identified as the second most important to the respondents is research and education programs as addressed in Title VII of the 2002 Farm Bill. The FNGLA and Farm Bureau groups identified research and education as the second most critical issue, behind labor, while the Florida Tomato Exchange respondents identified research and education as their first priority. Of the issues that are directly addressed in the Farm Bill, research and education was clearly identified as the most important program to specialty crop growers. All respondents believed that federal funding for agricultural research at public universities should be increased. They were also supportive $(91.6 \%)$ of federal funding for agricultural research being conducted by private companies. The research area they feel should receive the most attention is production technologies, followed by the general grouping of value-added products, invasive species management, and marketing and promotion.

The third and fourth most important issues were disaster assistance and insurance programs. It is not all that surprising that disaster assistance was identified as important to these growers. Many of the respondents were affected in one way or another by hurricanes in 2004 and 2005, and disaster relief was identified as important to their organizations. The majority $(76.2 \%)$ of the survey respondents felt that the current practice of paying disaster assistance should be maintained. Crop insurance was viewed as important to FNGLA and Farm Bureau respondents. It is important to note that crop insurance came up in discussions during the listening sessions, because many growers feel the programs need to be improved, not removed. The two most important types of insurance identified by the respondents were catastrophic risk and multiple-peril (APH) insurance products. Crop revenue, whole-farm revenue, and whole-farm income insurance products came in much lower as products important for managing risk.

Conservation programs and energy policy were the next highest rated issues (both received similar rankings of fifth) for all groups. Conservation programs are covered in Title II of the current farm bill. A common theme voiced during the listening sessions about conservation programs was the complexity of the programs and the difficulty many groups have in participating in these programs. A further inquiry on the conservation programs revealed that an overwhelming majority believes the federal government should provide financial incentives to growers to conserve environmental amenities. The conservation reserve program (CRP) and environmental quality incentives program (EQIP) were the only programs that more than half the respondents knew about $(62 \%$ and $71 \%$, respectively). No program was identified by more than half of the respondents as being effective. It is particularly worth noting that only $23.8 \%$ of the respondents were familiar with the Conservation Security Program (CSP). The general theme of these results and the discussions at the listening sessions is that these programs are not well-written for specialty crop growers to participate, and that even when they 
are well-written, they are difficult to understand and it is difficult to apply for them.

Energy policy related to agriculture was ranked similar to conservation in the degree of importance. Energy policy related to agriculture is outlined in Title IX of the 2002 Farm Bill. The respondents were split on whether the government should be involved in regulating energy markets. A majority $(66.7 \%)$ indicated that the government should be involved in subsidizing the production of alternative fuels.

The category of small farm programs was the seventh highest rated issue of importance to specialty crop growers. Small farm programs are generally tied to the Farm Credit System for support, as addressed in Title V of the current Farm Bill. The survey asked two additional questions about small farm programs: 1) should more farm credit be targeted to small farms and 2) should tax credits be provided to encourage small farms and beginning farmers? Respondents were split on the idea of targeting more farm credit programs to small farms and beginning growers but were slightly supportive $(67.5 \%)$ of providing tax credits to encourage small or beginning growers.

The next highest rated issue of importance (eighth) in the Farm Bill was trade policy, which is addressed in Title III of the current Farm Bill. The survey asked more detailed questions about trade policy. Respondents were first asked to indicate whether they believed specialty crop growers benefited from international trade. The response indicates that almost all groups were split on this issue, with half indicating that specialty crop growers do benefit from international trade and half disagreeing with that view. In a ranking of trade policy goals, preventing the import of invasive species was the number one issue identified by all groups. The second most important goal identified by these growers was protecting domestic growers from offshore competition, followed closely by preventing foreign exporters from dumping in U.S. markets. All three priorities relate to creating an environment of fair and safe trade.

Federal block grants were ranked similar to trade policy in importance. Devolution of farm programs to the state is an issue that some specialty crop groups have promoted to provide more equitable treatment in
Farm Bill support across commodity groups. A majority $(67.5 \%)$ of the respondents felt the federal government should administer farm safety net programs. While the respondents were split on the management of biofuels support, a majority supported the state administering environmental and natural resource programs $(66.7 \%)$, agricultural sustainability programs $(75.0 \%)$, and agricultural research $(58.4 \%)$.

The other issues presented in the survey received rankings below the above discussed programs. It is not surprising that income support programs are not viewed as an important issue to specialty crop growers. Those who did believe the federal government should provide income support to specialty crop growers felt that the two programs that held the greatest likelihood of providing benefits to specialty crop growers were revenue insurance and market loss assistance. The other typical programs used for income support (direct payments, countercyclical payments, and non-recourse marketing loans) all ranked significantly below revenue insurance and market loss assistance.

Growers also rated food assistance and nutrition of little benefit to specialty crop growers. It was generally recognized, however, that the fruit and vegetable pilot program and a change in the food pyramid are the two most important food and nutrition programs to specialty crop growers.

Finally, growers were asked in the survey whether they supported labeling and market information. All growers (100\%) believed that labeling should be used to identify country of origin on food products, but were split in their view $(47.7 \%$ supported) on whether the federal government should increase efforts to improve the traceability of food products back to the source. Growers do support (81\%) the federal government providing market information.

\section{Conclusions}

Listening sessions held in Florida highlight the need for more research and education on farm policy. Not only is research and education perceived by these groups as an area that needs more attention by the federal government, but the listening session 
experience also highlighted the lack of knowledge about various farm programs available within the Farm Bill. Many growers think of the Farm Bill from the perspective of Title I Commodity Programs that provide income support to program crops. They often fail to associate conservation programs and disaster assistance as critical elements of farm policy to the Farm Bill. The results of our meetings and surveys do indicate, however, that growers see research and education as the most important program area. Specialty crop growers do not see great benefits from an income support program similar to current program crops in Title I of the Farm Bill. After discussions with the groups, they do recognize the value of the specialty crop planting restriction for program crop growers, and many believe they should be compensated if the planting restriction is removed from the 2007 Farm Bill.

\section{References}

Hodges, Alan, and David Mulkey. 2006.

Economic Impacts of Agricultural and Natural Resource Industries in Florida. University of Florida Economic Impact Analysis Center, Gainesville, FL

(February).

http://economicimpact.ifas.ufl.edu/publications//

General/Fla_Ag_Nat_Resource_Ind\%202003.pdf.

United States Department of Agriculture. 2005. Transcript of the Florida Farm Bill Forum with Agriculture Secretary Mike Johanns and Moderator Gary Cooper of Southeast AgriNet Orlando, Florida September 27, 2005. USDA Transcript Release No. 0439.05. United States Department of Agriculture, Washington, D.C.

http://www.usda.gov/documents/FBFFL092705.doc 